Article

\title{
Synthesis of Nano-Calcium Oxide from Waste Eggshell by Sol-Gel Method
}

\author{
Lulit Habte $^{1}{ }^{\mathbb{D}}$, Natnael Shiferaw ${ }^{2}$, Dure Mulatu ${ }^{1}$, Thriveni Thenepalli ${ }^{3}{ }^{\mathbb{D}}$, \\ Ramakrishna Chilakala ${ }^{4}$ and Ji Whan Ahn ${ }^{3, *}$ \\ 1 Department of Resources Recycling, University of Science \& Technology, 217 Gajeong-ro, Gajeong-dong, \\ Yuseong-gu, Daejeon 34113, Korea; luna1991@ust.ac.kr (L.H.); dure@kigam.re.kr (D.M.) \\ 2 Korea Research Institute of Climate Change, 11, Subyeongongwon-gil, Chuncheon-si 24239, Korea; \\ natlulit@gmail.com \\ 3 Center for Carbon Mineralization, Mineral Resources Division, Korea Institute of Geosciences and Mineral \\ Resources (KIGAM), 124 Gwahagno, Gajeong-dong, Yuseong-gu, Daejeon 34132, Korea; \\ thenepallit@rediffmail.com \\ 4 Department of Bio-based Materials, School of Agriculture and Life Science, Chungnam National University, \\ Daejeon City 34134, Korea; chilakala_ramakrishna@rediffmail.com \\ * Correspondence: ahnjw@kigam.re.kr
}

Received: 30 April 2019; Accepted: 3 June 2019; Published: 7 June 2019

check for updates

\begin{abstract}
The sol-gel technique has many advantages over the other mechanism for synthesizing metal oxide nanoparticles such as being simple, cheap and having low temperature and pressure. Utilization of waste materials as a precursor for synthesis makes the whole process cheaper, green and sustainable. Calcium Oxide nanoparticles have been synthesized from eggshell through the sol-gel method. Raw eggshell was dissolved by $\mathrm{HCl}$ to form $\mathrm{CaCl}_{2}$ solution, adding $\mathrm{NaOH}$ to the solution dropwise to agitate $\mathrm{Ca}(\mathrm{OH})_{2}$ gel and finally drying the gel at $900{ }^{\circ} \mathrm{C}$ for $1 \mathrm{~h}$. The synthesized nanoparticle was characterized by scanning electron microscope (SEM), Fourier-transform infrared spectroscopy (FTIR), X-Ray fluorescence (XRF) and X-ray diffraction (XRD). The FTIR and XRD results have clearly depicted the synthesis of calcium oxide from eggshell, which is mainly composed of calcium carbonate. The FE-SEM images of calcium oxide nanoparticles showed that the particles were almost spherical in morphology. The particle size of the nanoparticles was in the range $50 \mathrm{~nm}-198 \mathrm{~nm}$. Therefore, waste eggshell can be considered as a promising resource of calcium for application of versatile fields.
\end{abstract}

Keywords: calcium oxide nanoparticle; sol-gel method; eggshell

\section{Introduction}

Ever increasing solid waste is now becoming a challenge for a sustainable world. Improper management of those wastes leads to public health and environment related problems [1]. Huge amounts of solid wastes, including municipal, industrial and hazardous wastes, have been generated worldwide. Food wastes are the major solid wastes causing problems in the environment. It was estimated that food waste would increase by $44 \%$ from 2005 to 2025 [2]. Industrialization and population growth are the major factors for the increase in solid wastes. Eggshell is a solid waste which contributes to degradation in the environment. Households, restaurants, and bakeries are the major source of eggshell [3]. The main component is pure calcium carbonate with little porosity [3]. This waste can be transformed into valuable products. Eggshells can also be used as a $\mathrm{CaCO}_{3}$ source for different applications [4,5]. However, the common trend to manage waste eggshell is land filling which causes problems for the environment. Landfilling such food wastes cause unpleasant odors 
during biodegradation and the attached membranes attract worms and insects. Utilization of eggshells can provide benefits, not only regarding environmental concerns but also for freeing up landfill sites.

Synthesis of nanoparticles is attracting more attention because of better performance in terms of improved surface area. Metal oxide nanoparticles have many applications in diverse fields. They are considered as an active catalyst for versatile applications [6]. Metal oxide nanoparticles have been utilized as adsorbents for heavy metals removal in water and wastewater [7-11], as sorbents for $\mathrm{CO}_{2}$ capture [12] where $\mathrm{CO}_{2}$ capture increases with the increase in surface area of the particle [13], as heterogeneous catalysts in biodiesel production [14], as purification of exhaust gas [15] and in wall painting [16]. Calcium oxide, magnesium oxide, aluminum oxide, zinc oxide, manganese dioxide, titanium oxides, and iron oxide nanoparticles are the most commonly used nano-metal oxides. These metal oxide nanoparticles have been synthesized by several methods such as the ultrasonic-assisted method [17], the hydrogen plasma-metal reaction method [18], the biopolymer-assisted method [19] microwave-assisted method [20], facial calcination [21], co-precipitation [22], direct thermal decomposition [23], chemical co-precipitation [24], two-step process (green synthesis) [25] and two step thermal decomposition [26]. Those methods have drawbacks, such as the use of additives, high temperature, and pressure, time-consuming, expensive and complicated procedures. Sol-gel method overcomes most of the drawbacks from the above-mentioned methods. It is simple, cheap, not time consuming and no expensive equipment is required. It can also be carried out at lower temperature and with no pressure. Therefore, it can be a promising method to synthesize calcium oxide nanoparticles.

Nowadays, eggshell is being widely utilized for industrial applications $[4,5,11,27]$. Eggshell containing $\mathrm{CaCO}_{3}$ as a major constituent can be a potential candidate for calcium oxide nanoparticle synthesis. In this study, $\mathrm{CaO}$ nanoparticles were synthesized by sol-gel method in which raw eggshell was dissolved by $\mathrm{HCl}$ to form $\mathrm{CaCl}_{2}$ solution, adding $\mathrm{NaOH}$ to the solution dropwise to agitate $\mathrm{Ca}(\mathrm{OH})_{2}$ gel and finally drying the gel at high temperature. This method can be considered as cheap, easy and eco-friendly. The objective of this work is to utilize waste eggshell in wastewater treatment systems.

\section{Materials and Methods}

\subsection{Materials}

Chemicals, hydrochloric acid with 35\%-37\% concentration and sodium hydroxide with $97 \%$ purity were purchased from Junsei Chemicals Ltd., Seoul, Korea. Waste chicken eggshells were collected from the KIGAM (Korean Institute of Geoscience and Mineral Resources) campus restaurant in Daejeon, South Korea. Raw waste eggshell is mainly composed of $\mathrm{CaO}, \mathrm{MgO}, \mathrm{K}_{2} \mathrm{O}, \mathrm{P}_{2} \mathrm{O}_{5}, \mathrm{Na}_{2} \mathrm{O}$ and some trace compounds.

\subsection{Synthesis of Calcium Oxide Nanoparticles}

Synthesis of metal oxide nanoparticle through sol-gel method has four basic consecutive processes: Preparation of homogeneous solution, the formation of 'sol' by hydrolysis, the formation of 'gel' by condensation and drying of the formed gel [28]. In this experiment, a homogenous solution of metal salt, $\mathrm{CaCl}_{2}$, was produced by dissolving solid $\mathrm{CaCO}_{3}$ in dilute $\mathrm{HCl}$ as shown in Equation (1). Chicken eggshell was used as a precursor for this method. Waste eggshells were thoroughly washed with warm water and cleaned with deionized water. Then the washed sample was dried at $120^{\circ} \mathrm{C}$ for $2 \mathrm{~h}$, ground into a powder and sieved with $100 \mu \mathrm{m}$ sieve size. For the preparation of calcium chloride $\left(\mathrm{CaCl}_{2}\right)$ solution, $12.5 \mathrm{gm}$ of PES was dissolved in $250 \mathrm{~mL}$ of $1 \mathrm{M}$ hydrochloric acid $(\mathrm{HCl})$.

$$
\mathrm{CaCO}_{3}(\mathrm{~s})+2 \mathrm{HCl}(\mathrm{aq}) \rightarrow \mathrm{CaCl}_{2}(\mathrm{aq})+\mathrm{H}_{2} \mathrm{O}(\mathrm{l})+\mathrm{CO}_{2}(\mathrm{~g})
$$

The next step was the formation of 'sol' by hydrolysis process. 'Sol' is defined as a stable dispersion of colloidal particles of precursors in a solvent due to hydrolysis reaction. During the hydrolysis 
process, metal hydroxide was formed. A total of $250 \mathrm{~mL}$ of $1 \mathrm{M}$ sodium hydroxide $(\mathrm{NaOH})$ was added slowly (drop by drop) to convert the homogeneous $\mathrm{CaCl}_{2}$ solution formed in the previous step into 'sol' at ambient temperature (Equation (2)). Then 'gel' formation by condensation was followed. The slow addition of $\mathrm{NaOH}$ resulted in a low rate of nucleation and encouraged subsequent precipitation of $\mathrm{Ca}(\mathrm{OH})_{2}$ one over another forming a highly crystalline gel. The condensation reaction resulted in small-sized particles interconnected to each other forming a rigid and highly crystalline inorganic network within the liquid. $\mathrm{Ca}(\mathrm{OH})_{2}$ gel containing solution was aged for one night at ambient temperature.

$$
\mathrm{CaCl}_{2}(\mathrm{aq})+2 \mathrm{NaOH}(\mathrm{aq}) \rightarrow \mathrm{Ca}(\mathrm{OH})_{2}(\mathrm{~s})+2 \mathrm{NaCl}(\mathrm{aq})
$$

Then filtration followed where the filtrate was cleaned with distilled water in order to remove adsorbed impurities in the precipitate. The synthesizing process ended by drying the gel. In this process, the solvent (liquid phase) was removed and a significant amount of shrinkage and densification was noticed. The powder was dried at $60^{\circ} \mathrm{C}$ for $24 \mathrm{~h}$ in an oven and calcined at $900^{\circ} \mathrm{C}$ for $1 \mathrm{~h}$ (Equation (3)).

$$
\mathrm{Ca}(\mathrm{OH})_{2}(\mathrm{~s})+\mathrm{Heat} \rightarrow \mathrm{CaO}(\mathrm{s})+\mathrm{H}_{2} \mathrm{O}(\mathrm{l})
$$

\subsection{Characterization}

Characterization of powders was determined by thermogravimetric analysis (TGA), X-ray fluorescence (XRF), Fourier-transform infrared spectroscopy (FTIR), X-ray diffraction (XRD) and scanning electron microscope (SEM). Decomposition temperatures of Raw eggshell and $\mathrm{Ca}(\mathrm{OH})_{2}$ gel were analyzed by thermogravimetric analysis (TGA) (Shimadzu DTG-60H) in a platinum crucible at a heating rate of $10^{\circ} \mathrm{C} / \mathrm{min}$ from ambient temperature to $1000^{\circ} \mathrm{C}$. The chemical analysis of raw eggshell and synthesized $\mathrm{CaO}$ nanoparticle were performed using $\mathrm{X}$-ray fluorescence spectrometer (Shimadzu, Japan). The crystal structural analysis was analyzed by X-ray diffraction (XRD) with diffraction angles $2 \theta$ from ranging $10^{\circ}$ to $90^{\circ}$ and with $\mathrm{Cu} \mathrm{K} \alpha$ radiation $(\lambda=1.5406 \AA)$ as the radiation source. Size, shape and surface morphology of the nanoparticle was examined through field emission scanning electron microscope (FE-SEM), (Tuscan Mira 3 LMU FEG) with a coater (Quorum Q150T ES/10 mA, $120 \mathrm{~s}$ Pt coating) at an accelerating voltage of $10 \mathrm{kV}$. The FTIR spectroscopy (FT-IR) (6700 FTIR, Thermo Scientific Nicolet, Massachusetts, MA, USA) was used to determine the different functional groups present in the synthesized nanoparticle.

\section{Results}

Thermogravimetric analysis (TGA) curves of raw eggshell and $\mathrm{Ca}(\mathrm{OH})_{2}$ gel are illustrated in Figure $1 \mathrm{a}, \mathrm{b}$ respectively. In raw eggshell, a total weight loss of $39 \%$ was noticed and at $823{ }^{\circ} \mathrm{C}$ temperature $\mathrm{CO}_{2}$ is released to the environment. In the case of $\mathrm{Ca}(\mathrm{OH})_{2}$ gel, three major weight losses were observed in the analysis: $32{ }^{\circ} \mathrm{C}-461.89{ }^{\circ} \mathrm{C}, 461.89{ }^{\circ} \mathrm{C}-691.2{ }^{\circ} \mathrm{C}$ and $691.2^{\circ} \mathrm{C}-1000{ }^{\circ} \mathrm{C}$ with mass changes of $18.49 \%, 13.8 \%$ and $1.60 \%$ respectively. The losses correspond to vaporization of physically adsorbed water, decomposition of $\mathrm{Ca}(\mathrm{OH})_{2}$ gel to $\mathrm{CaO}$ and decomposition of $\mathrm{CaCO}_{3}$ to $\mathrm{CaO}$ where $\mathrm{CO}_{2}$ will be released [23]. 


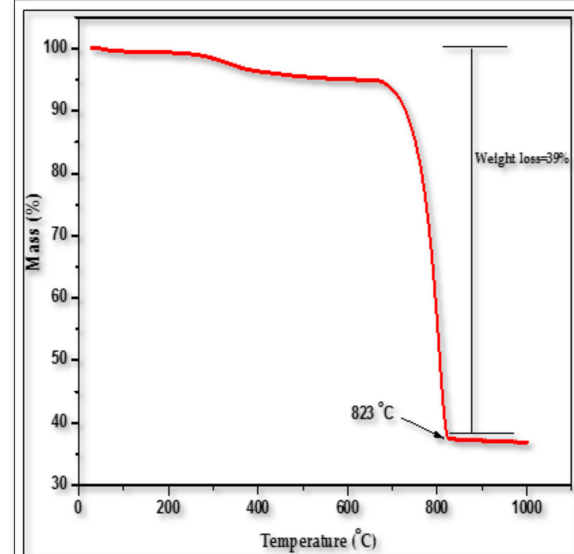

(a)

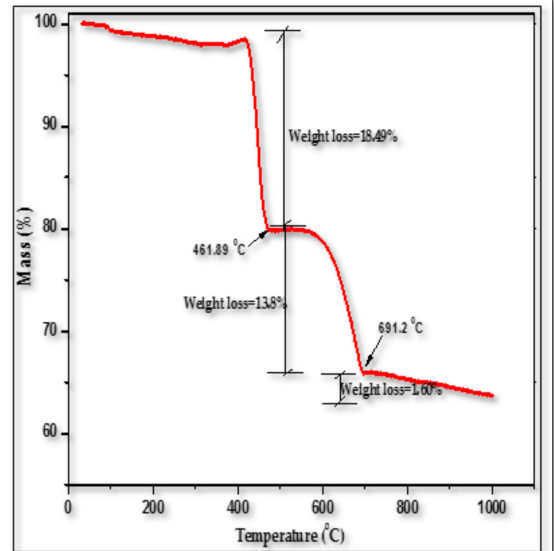

(b)

Figure 1. Thermogravimetric analysis (TGA) curve of (a) Raw eggshell, (b) $\mathrm{Ca}(\mathrm{OH})_{2}$ gel.

The chemical composition of raw eggshell and synthesized nanoparticle is listed in Table 1. The data below shows that $\mathrm{CaO}$ is the major quantity in the raw eggshell, which is mainly in the form of $\mathrm{CaCO}_{3}$ [29]. The High value of Ignition loss for raw eggshell represents the conversion of $\mathrm{CaCO}_{3}$ to $\mathrm{CaO}$ and $\mathrm{CO}_{2}$ during calcination [4]. After the synthesis of nanoparticle, lime was found to be the major component (86.93\%).

Table 1. Chemical analysis of raw eggshell and nanoparticle.

\begin{tabular}{cccccccccccc}
\hline $\begin{array}{c}\text { Chemical } \\
\text { Composition }\end{array}$ & $\mathrm{SiO}_{2}$ & $\mathrm{Al}_{2} \mathrm{O}_{3}$ & $\mathrm{Fe}_{2} \mathrm{O}_{3}$ & $\mathrm{CaO}$ & $\mathrm{MgO}$ & $\mathrm{K}_{2} \mathrm{O}$ & $\mathrm{Na}_{2} \mathrm{O}$ & $\mathrm{TiO}_{2}$ & $\mathrm{MnO}$ & $\mathrm{P}_{2} \mathrm{O}_{5}$ & Ig. Loss \\
\hline Raw eggshell (\%) & $<0.01$ & $<0.01$ & $<0.01$ & 52.75 & 0.52 & 0.04 & 0.05 & $<0.01$ & $<0.01$ & 0.22 & 46.62 \\
\hline Nano-CaO (\%) & 0.08 & 0.04 & 0.05 & 86.93 & 1.08 & 0.14 & 1.32 & $<0.01$ & $<0.01$ & 0.43 & 9.3 \\
\hline
\end{tabular}

FTIR spectrum of $\mathrm{CaO}$ nanoparticle, $\mathrm{Ca}(\mathrm{OH})_{2}$ gel, raw eggshell and commercial $\mathrm{CaO}, \mathrm{Ca}(\mathrm{OH})_{2}$ and $\mathrm{CaCO}_{3}$ are presented in Figure 2 to characterize the synthesized nanoparticle and also to compare the results with the commercial powders. The FTIR result of the raw eggshell showed broadband centering at $1415.52 \mathrm{~cm}^{-1}$ which is a characteristic of $\mathrm{C}-\mathrm{O}$ bond showing a bond between the oxygen atom of carbonate and calcium atom [30]. In addition, there were two sharp bands at 711.62 and $875.54 \mathrm{~cm}^{-1}$ showing $\mathrm{C}-\mathrm{O}$ bond [30]. The peaks of raw eggshell were in correspondence with commercial $\mathrm{CaCO}_{3}$ except for the broadband at $2360.48 \mathrm{~cm}^{-1}$ which represents the $\mathrm{N}-\mathrm{H}$ bond caused by the amines and amides present in the protein fiber of the eggshell membrane [31]. On the other hand, $\mathrm{CaO}$ nanoparticles showed peaks at $1444.42 \mathrm{~cm}^{-1}, 1064.51 \mathrm{~cm}^{-1}$, and $863.95 \mathrm{~cm}^{-1}$ which were ascribed to $\mathrm{C}-\mathrm{O}$ bond indicating the carbonation of calcium oxide nanoparticles $[18,24]$. The absorption peak at $3639.02 \mathrm{~cm}^{-1}$ has also resulted due to the $\mathrm{O}-\mathrm{H}$ bond from water molecules on the surface of the nanoparticle [18,24]. The tiny peak at $2343.09 \mathrm{~cm}^{-1}$ might be due to atmospheric $\mathrm{CO}_{2}$ [32]. This peak has also been seen in commercial $\mathrm{CaO}$ and $\mathrm{Ca}(\mathrm{OH})_{2}$. The absence of a sharp absorption in the region at $1415.52 \mathrm{~cm}^{-1}$ indicates that the $\mathrm{CaCO}_{3}$ as the basic component of the eggshell was no longer present as it was already converted to $\mathrm{CaO}$. The strong band at $512 \mathrm{~cm}^{-1}$ identified vibration of the $\mathrm{Ca}-\mathrm{O}$ band $[20,24]$. 


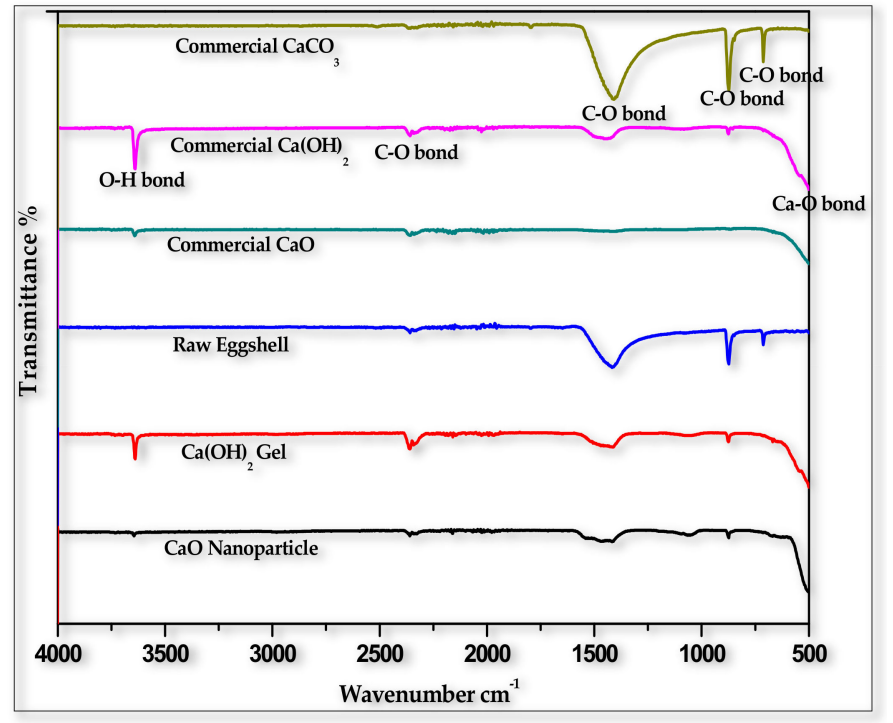

Figure 2. FTIR spectrum of $\mathrm{CaO}$ Nanoparticle, $\mathrm{Ca}(\mathrm{OH})_{2} \mathrm{Gel}$, Raw eggshell and Commercial $\mathrm{CaO}$, $\mathrm{Ca}(\mathrm{OH})_{2}$ and $\mathrm{CaCO}_{3}$.

XRD results of raw eggshell, commercial $\mathrm{Ca}(\mathrm{OH})_{2}, \mathrm{Ca}(\mathrm{OH})_{2}$ gel and synthesized calcium oxide nanoparticle are shown in Figure 3. Raw eggshell XRD pattern showed a good match with $\mathrm{CaCO}_{3}$ in the calcite phase (PDF Card No. 00-081-2027). The main peak appeared at $2 \theta=29.48$. In addition, the analysis shows several peaks at $23.07,31.52,36.06,39.48,43.26,47.64,48.6,56.62,57.5,60.92,63.2$, $64.76,65.74,70.29,72.96,76.37,82.15,84.9$ which are assigned to (012), (006), (110), (113), (202), (018), (116), (211), (122), (214), (300), (0012), (0210), (128), (220), (114), (226) planes of calcite phase respectively. XRD patterns of $\mathrm{Ca}(\mathrm{OH})_{2}$ gel match with portlandite phase (PDF Card No. 00-087-0673) as a major phase and also with commercial $\mathrm{Ca}(\mathrm{OH})_{2}$ as shown the figure. The main peak of the gel appeared at $2 \theta=34.12$. In the case of synthesized calcium oxide nanoparticle (Figure 3 ), the XRD patterns match with calcium oxide (CaO) (PDF Card No. 99-0070). The main peak appeared at $2 \theta=37.4$. Besides, several peaks appeared at 32.22, 37.36, 53.9, 64.2, 67.4, 79.7 and 88.58 which are also assigned to (111), (200), (220), (311), (222), (400), and (331) planes of lime phase respectively. The result shows that the calcium carbonate in the raw eggshell was completely changed to calcium oxide during the synthesis.

Scherrer's Equation (Equation (4)) was used to calculate the mean crystallite size of the calcium oxide nanoparticle:

$$
\mathrm{d}=\frac{\mathrm{k} \lambda}{\beta \cos \theta}
$$

where $d$ is mean crystallite size, $\lambda$ is wavelength, $k$ is constant of Scherrer, $\theta$ is Bragg's angle and $\beta$ is structural broadening. Accordingly, the mean size of crystallite was found to be $24.51 \mathrm{~nm}$. Other researchers using this technique of nanoparticle synthesis (sol-gel) have also confirmed the formation of large crystallite size. It was reported that the synthesis of $\mathrm{MgO}$ nanoparticles with an average particle size of $27.0 \mathrm{~nm}$ using the sol-gel technique [33]. Other studies also reported that the synthesized calcium oxide nanoparticle had a crystallite size of $40 \mathrm{~nm}$ and $41 \mathrm{~nm}$ for two different conditions [24]. Moreover, the lattice strain of crystal was determined by Equation (5):

$$
\varepsilon=\frac{\beta}{4 \tan \theta}
$$

where $\theta$ is Bragg's angle, $\beta$ is structural broadening, $\varepsilon$ is lattice strain. Therefore, it was determined as $4.41 \times 10^{-3}$. 


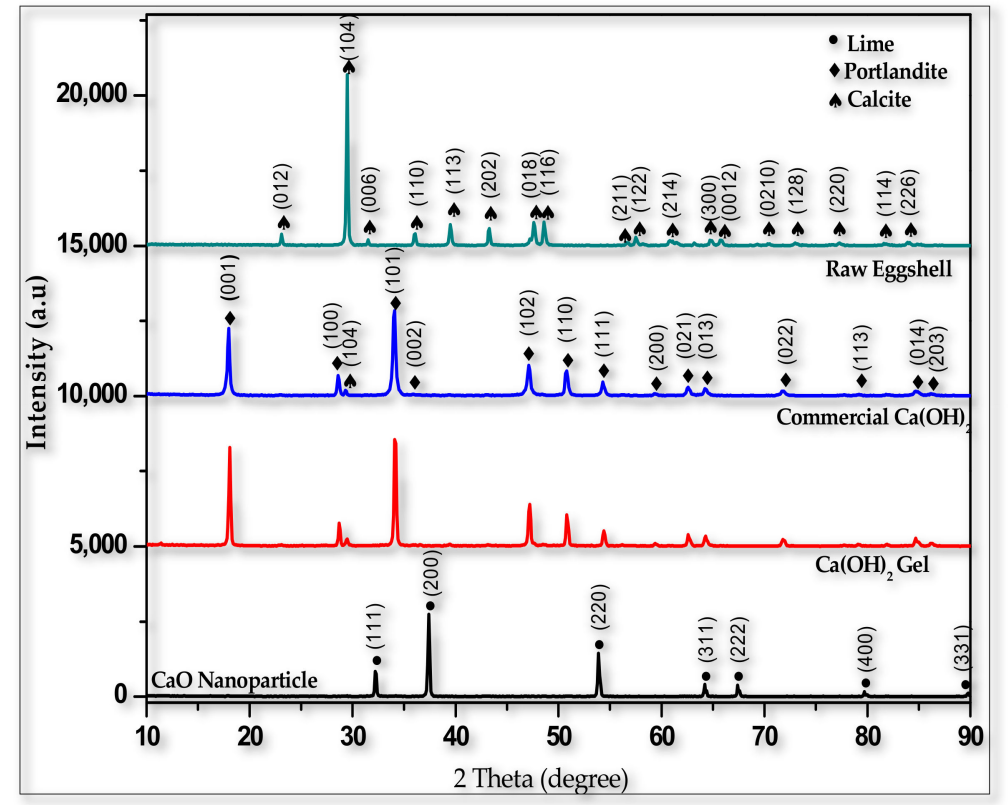

Figure 3. X-ray Diffraction of a Raw eggshell, Commercial $\mathrm{Ca}(\mathrm{OH})_{2}, \mathrm{Ca}(\mathrm{OH})_{2} \mathrm{Gel}$ and $\mathrm{CaO}$ nanoparticle.

Surface morphology of $\mathrm{Ca}(\mathrm{OH})_{2}$ gel and synthesized calcium oxide nanoparticle was studied by FE-SEM as shown in Figure 4ab. Raw eggshell had a non-porous and irregular crystal structure. In Figure 4a, the surface micro structural analysis, using SEM, of $\mathrm{Ca}(\mathrm{OH})_{2}$ gel has been analyzed to study the transition from gel to nanoparticle obtained after drying. The result revealed that the $\mathrm{Ca}(\mathrm{OH})_{2}$ gel has a hexagonal shape in which the size is also in nano-scale (around $450 \mathrm{~nm}$ ). This result has also been obtained from other research of synthesizing $\mathrm{Ca}(\mathrm{OH})_{2}$ nano-plates from oyster shells [34]. FE-SEM image shown in Figure $4 \mathrm{~b}$ showed that the nanoparticles are approximately spherical in morphology agglomerating to each other. These agglomerates of small particles show the polycrystalline character of the nanoparticle. Other studies confirmed the spherical shape of calcium oxide nanoparticles [17,24]. Mean size of $\mathrm{CaO}$ nanoparticle was estimated to be $198 \mathrm{~nm}$, as seen in Figure 5. Size of calcium oxide nanoparticle was reduced after drying the $\mathrm{Ca}(\mathrm{OH})_{2}$ gel due to the release of $\mathrm{CO}_{2}$ and $\mathrm{H}_{2} \mathrm{O}$. A calcination temperature of $900{ }^{\circ} \mathrm{C}$ was used, at which vaporization of absorbed water and decomposition of $\mathrm{Ca}(\mathrm{OH})_{2}$ and $\mathrm{CaCO}_{3}$ to $\mathrm{CaO}$ occurred. This result was also confirmed by XRD result where lime was obtained from the synthesis.

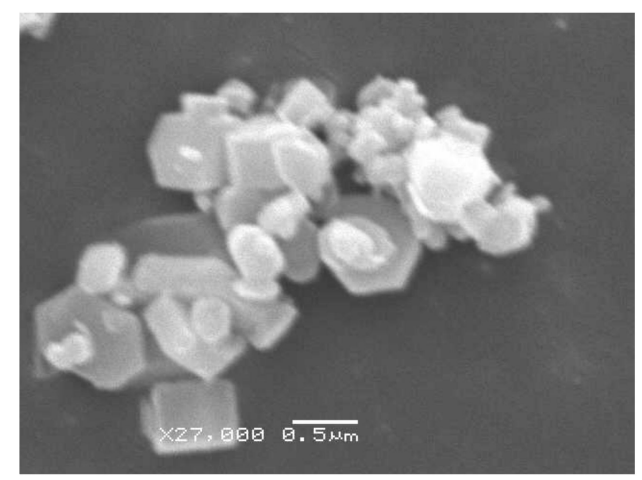

(a)

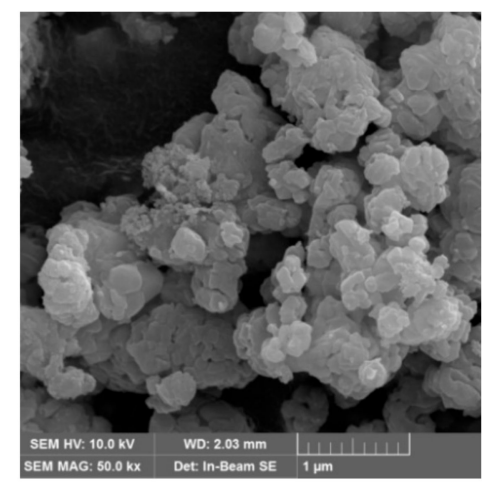

(b)

Figure 4. Scanning electron microscopy images of $(\mathbf{a}) \mathrm{Ca}(\mathrm{OH})_{2}$ gel, and (b) synthesized $\mathrm{CaO}$ nanoparticle. 


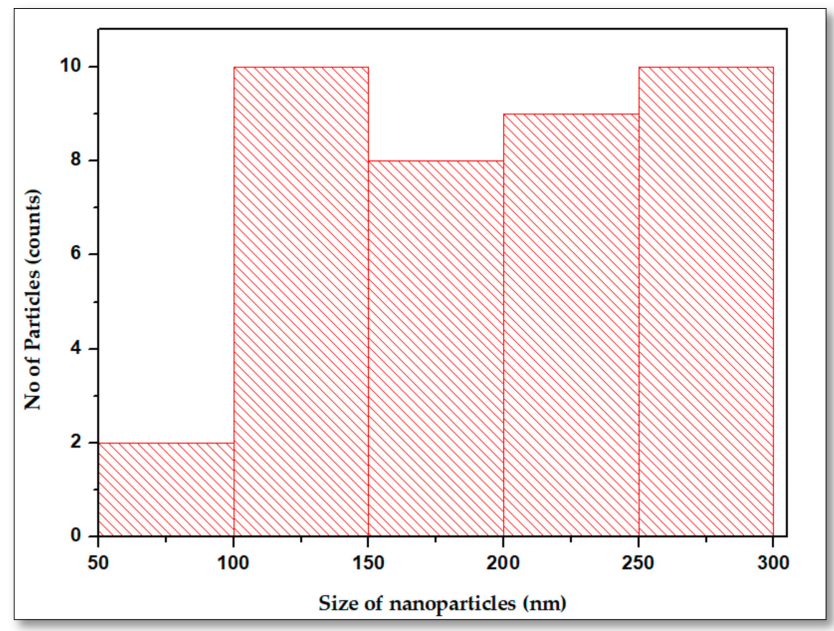

Figure 5. Particle size distribution of nano-calcium oxide.

Table 2 briefly summarizes comparison between current and other method of calcium oxide nanoparticle synthesis. Although particle size obtained in this technique is higher than other methods, it has advantages over the other methods. It is very simple, cheap, does not require expensive equipment, takes only a short time and has no additives. Moreover, in the synthesis process, ambient temperature was used, contributing to less energy consumption. Other methods used higher temperature, polymer additives, expensive equipment and took a longer time.

Table 2. Brief summary of $\mathrm{CaO}$ nanoparticles synthesis methods.

\begin{tabular}{|c|c|c|}
\hline Method & Summary & Reference \\
\hline Facial calcination & $\begin{array}{l}\text { A total of } 50 \mathrm{~nm} \text { of calcium oxide nano-particles were } \\
\text { obtained by facile thermal treating of calcite at } 900^{\circ} \mathrm{C} \\
\text { temperature for } 5 \mathrm{~h} \text { and then by lime hydrolysis. }\end{array}$ & Malekzadeh et al., 2012 [21] \\
\hline Microwave irradiation & $\begin{array}{l}\text { By microwave processing, the calcium oxide } \\
\text { nano-particles were obtained at } 160^{\circ} \mathrm{C} \text { temperature } \\
\text { in the } 5 \text { min with the average particle size is } 14 \sim 24 \\
\mathrm{~nm} \text {. }\end{array}$ & $\begin{array}{l}\text { Jayanta Bhattacharya et al., } \\
2013 \text { [20] }\end{array}$ \\
\hline Co-Precipitation & $\begin{array}{l}\mathrm{CaO} \text { nano-particles are synthesized by the co } \\
\text { precipitation method, in presence of } \\
\text { polyvinylpyrrolidone (PVP) reagent for control the } \\
\text { agglomeration. The average time takes for this } \\
\text { synthesis was } 12 \mathrm{~h} \text { at } 40^{\circ} \mathrm{C} \text { temperature. The average } \\
\text { size of the nano-particles are } 100 \mathrm{~nm} \text {. }\end{array}$ & $\begin{array}{l}\text { Meysam Sadeghi et al., } \\
2013 \text { [22] }\end{array}$ \\
\hline $\begin{array}{l}\text { Direct thermal } \\
\text { decomposition }\end{array}$ & $\begin{array}{l}\text { Calcium oxide nano-particles were synthesized by } \\
\text { direct thermal decomposition method at } 80^{\circ} \mathrm{C} \text { by } \\
\text { blowing inert argon gas with the average particle size } \\
\text { is } 91 \mathrm{~nm} \sim 94 \mathrm{~nm} \text {. }\end{array}$ & $\begin{array}{l}\text { Fereshteh Bakhtiari et al., } \\
2014[23]\end{array}$ \\
\hline $\begin{array}{l}\text { Chemical } \\
\text { co-precipitation }\end{array}$ & $\begin{array}{l}\text { Chemical co-precipitation was applied for the } \\
\text { synthesis of calcium oxide nano-particles in presence } \\
\text { of polyvinyl alcohol. The average particle size is } 11 \\
\mathrm{~nm} \text { at } 80^{\circ} \mathrm{C} \text { for } 60 \mathrm{~min} \text {. }\end{array}$ & Ali et al., 2015 [24] \\
\hline $\begin{array}{l}\text { Two step process } \\
\text { (Green synthesis) }\end{array}$ & $\begin{array}{l}\text { CaO nano-particles were synthesized from shrimp } \\
\text { cells by two step process with the average particle } \\
\text { size is } 40 \text { to } 130 \mathrm{~nm} \text {. }\end{array}$ & Hui-Fen Wu et al., 2015 [25] \\
\hline $\begin{array}{l}\text { Two step thermal } \\
\text { decomposition }\end{array}$ & $\begin{array}{l}\text { Crystallite size of calcium oxide nano-particles were } \\
\text { obtained by } 2 \text { step thermal decomposition method. }\end{array}$ & Arul et al., 2018 [26] \\
\hline $\begin{array}{l}\text { Sol-gel method (present } \\
\text { authors used) }\end{array}$ & $\begin{array}{l}\text { A total of } 50-198 \mathrm{~nm} \text { of calcium oxide nanoparticles } \\
\text { was obtained at ambient temperature, with less cost, } \\
\text { no additives, shorter time and a calcination } \\
\text { temperature of } 900^{\circ} \mathrm{C} \text { for } 1 \mathrm{~h} \text { only. }\end{array}$ & Ahn et al., 2019 \\
\hline
\end{tabular}




\section{Conclusions}

In this paper, calcium oxide nanoparticles were synthesized from waste eggshell through the sol-gel method. Sol-gel technique has many key advantages over other methods for synthesizing metal oxide nanoparticles, such as being simple, economic, requiring no expensive equipment, ambient temperature and having no pressure. The FTIR and XRD results have clearly depicted the synthesis of calcium oxide from eggshell, which was mainly composed of calcium carbonate. The FE-SEM images of Calcium Oxide nanoparticles showed that the particles were almost spherical in morphology. The mean particle size of the nanoparticles was $198 \mathrm{~nm}$. But this result can be improved if higher temperature is used. The synthesized nanoparticle can be applied for future studies in heavy metal removal from industrial wastewater. Moreover, utilizing waste materials as a precursor for the synthesis makes the whole process cheaper, green and sustainable. Waste eggshell can further be used in future work for the synthesis of nano-calcium carbonate, which can be applied as a filler material in the automobile and paper industry.

Author Contributions: L.H., N.S., D.M., conducted the experiments and wrote the manuscript. T.T., R.C. collected the information, analyzed the data and A.J.W. corrected the final manuscript and agreed to submit this data to the sustainability journal.

Funding: This research was funded by Ministry of Science and ICT(MSIT), the Ministry of Environment (ME) and the Ministry of Trade, Industry, and Energy (MOTIE) and the Grant number [2017M3D8A2084752] and the APC National Strategic Project-Carbon Mineralization Flagship Center of the National Research Foundation of Korea (NRF).

Acknowledgments: This research was supported by the National Strategic Project-Carbon Mineralization Flagship Center of the National Research Foundation of Korea (NRF) funded by the Ministry of Science and ICT(MSIT), the Ministry of Environment (ME) and the Ministry of Trade, Industry, and Energy (MOTIE). (2017M3D8A2084752).

Conflicts of Interest: The authors declare no conflict of interest.

\section{References}

1. Ejaz, N.; Akhtar, N.; Nisar, H.; Ali Naeem, U. Environmental impacts of improper solid waste management in developing countries: A case study of Rawalpindi city. WIT Trans. Ecol. Environ. 2010, 142, 379-387. [CrossRef]

2. Mavropoulos, A.; Wilson, D.; Cooper, J.; Costas, V.; Appelqvist, B. Globalization and Waste Management; International Solid Waste association (ISWA): Vienna, Austria, 2012; pp. 1-55.

3. Akbar, A.; Hamideh, F. Application of eggshell wastes as valuable and utilizable products: A review. Res. Agric. Eng. 2018, 64, 104-114. [CrossRef]

4. Jose Valente, F.C.; Roberto, L.R.; Jovita, M.B.; Rosa María, G.C.; Antonio, A.P.; Gladis Judith, L.D. Sorption mechanism of Cd(II) from water solution onto chicken eggshell. App. Sur. Sci. 2013, 276, 682-690. [CrossRef]

5. Duncan, C.; Allison, R. Sustainable bio-inspired limestone eggshell powder for potential industrialized applications. ACS Sustain. Chem. Eng. 2015, 3, 941-949. [CrossRef]

6. Gerko, O. Metal oxide nanoparticles: Synthesis, characterization, and application. J. Sol. Gel Sci. Technol. 2006, 37, 161-164. [CrossRef]

7. Ming, H.; Shujuan, Z.; Bingcai, P.; Weiming, Z.; Lu, L.; Quanxing, Z. Heavy metal removal from water/wastewater by nanosized metal oxides: A review. J. Hazard. Mater. 2012, 211-212, 317-331. [CrossRef]

8. Lin, X.; Burns, R.C.; Lawrance, G.A. Heavy metals in wastewater: The effect of electrolyte composition on the precipitation of cadmium (ii) using lime and magnesia. Water Air Soil Pollut. 2005, 165, 131-152. [CrossRef]

9. El-Dafrawy, S.M.; Youssef, H.M.; Toamah, W.O.; El-Defrawy, M.M. Synthesis of nano-CaO particles and its application for the removal of Copper (II), Lead (II), Cadmium (II) and Iron (III) from aqueous solutions. Egypt. J. Chem. 2015, 58, 579-589. [CrossRef]

10. Oladoja, N.A.; Ololade, I.A.; Olaseni, S.E.; Olatujoye, V.O.; Jegede, O.S.; Agunloye, A.O. Synthesis of nano calcium oxide from a gastropod shell and the performance evaluation for $\mathrm{Cr}$ (VI) removal from aqua system. Ind. Eng. Chem. Res. 2012, 51, 639-648. [CrossRef]

11. Setiawan, B.D.; Oviana, R.; Fadhilah Brilianti, N.; Wasito, H. Nanoporous of waste avian eggshell to reduce heavy metal and acidity in water. Sus. Chem. Phar. 2018, 10, 163-167. [CrossRef] 
12. Wenqiang, L.; An, H.; Qin, C.; Yin, J.; Wang, G.; Feng, B.; Xu, M. Performance enhancement of calcium oxide sorbents for cyclic $\mathrm{CO}_{2}$ capture-A review. Energy Fuels 2012, 26, 2751-2767. [CrossRef]

13. Nikulshina, V.; G'alvez, M.E.; Steinfeld, A. Kinetic analysis of the carbonation reactions for the capture of $\mathrm{CO}_{2}$ from air via the $\mathrm{Ca}(\mathrm{OH})_{2}-\mathrm{CaCO}_{3}-\mathrm{CaO}$ solar thermochemical cycle. Chem. Eng. J. 2007, 129, 75-83. [CrossRef]

14. Boeya, P.L.; Pragas Maniama, G.; Abd Hamid, S. Performance of calcium oxide as a heterogeneous catalyst in biodiesel production. A review. Chem. Eng. J. 2011, 168, 15-22. [CrossRef]

15. Bharathiraja, B.; Sutha, M.; Sowndarya, K.; Chandran, M.; Yuvaraj, D.; Praveen Kumar, R. Calcium Oxide Nanoparticles as an Effective Filtration aid for Purification of Vehicle Gas Exhaust; Srivastava, D.K., Ed.; Springer: Singapore, 2018.

16. Chelazzi, D.; Poggi, G.; Jaidar, Y.; Toccafondi, N.; Giorgi, R.; Baglioni, P. Hydroxide nanoparticles for cultural heritage: Consolidation and protection of wall paintings and carbonate materials. J. Colloid Interface Sci. 2013, 392, 42-49. [CrossRef] [PubMed]

17. Alavi, M.A.; Morsali, A. Ultrasonic-assisted synthesis of $\mathrm{Ca}(\mathrm{OH})_{2}$ and $\mathrm{CaO}$ nanostructures. J. Exp. Nano Sci. 2010, 5, 93-105. [CrossRef]

18. Liu, T.; Zhu, Y.; Zhang, X.; Zhang, T.; Zhang, T.; Li, X. Synthesis and characterization of calcium hydroxide nanoparticles by hydrogen plasma-metal reaction method. Mater. Lett. 2010, 64, 2575-2577. [CrossRef]

19. Darroudia, M.; Bagherpour, M.; Ali Hosseinie, H.; Ebrahimic, M. Biopolymer-assisted green synthesis and characterization of calcium hydroxide nanoparticles. Ceram. Int. 2016, 42, 3816-3819. [CrossRef]

20. Roy, A.; Bhattacharya, J. Microwave assisted synthesis of $\mathrm{CaO}$ nanoparticles and use in waste water treatment. Nano Technol. 2011, 3, 565-568.

21. Roy, A.; Gauri, S.S.; Bhattacharya, M.; Bhattacharya, J. Antimicrobial Activity of CaO Nanoparticles. J. Biomed. Nanotechnol. 2013, 9, 1-8. [CrossRef]

22. Ghiasi, M.; Malekzadeh, A. Synthesis of $\mathrm{CaCO}_{3}$ nanoparticles via citrate method and sequential preparation of $\mathrm{CaO}$ and $\mathrm{Ca}(\mathrm{OH})_{2}$ nano particles. Cryst. Res. Technol. 2012, 47, 471-478. [CrossRef]

23. Sadeghi, M.; Husseini, M.H. A Novel Method for the Synthesis of CaO Nanoparticle for the Decomposition of Sulfurous Pollutant. J. Appl. Chem. Res. 2013, 7, 39-49.

24. Mirghiasi, Z.; Bakhtiari, F.; Darezereshki, E.; Esmaeilzadeh, E. Preparation and characterization of CaO nanoparticles from $\mathrm{Ca}(\mathrm{OH})_{2}$ by direct thermal decomposition method. J. Ind. Eng. Chem. 2014, 20, 113-117. [CrossRef]

25. Butt, A.R.; Ejaz, S.J.; Baron, C.; Ikram, M.; Ali, S. CaO nanoparticles as a potential drug delivery agent for biomedical applications. Dig. J. Nanomater. Biostruct. 2015, 10, 799-809.

26. Gedda, G.; Pandey, S.; Lina, Y.C.; Wu, H.F. Antibacterial effect of calcium oxide nano-plates fabricated from shrimp shells. Green Chem. 2015, 17, 3276-3280. [CrossRef]

27. Arul, E.; Raja, K.; Krishnan, S.; Sivaji, K.; Jerome, D.S. Bio-Directed synthesis of calcium oxide (Cao) nanoparticles extracted from limestone using honey. J. Nanosci. Nanotechnol. 2018, 18, 5790-5793. [CrossRef] [PubMed]

28. Heung Jai, P.; Seong Wook, J.; Jae Kyu, Y.; Boo Gil, K.; Seung Mok, L. Removal of heavy metals using waste eggshell. J. Environ. Sci. 2007, 19, 1436-1441. [CrossRef]

29. Ferraz, E.; Gamelas, J.A.F.; Coroado, J.; Monteiro, C.; Rocha, F. Eggshell waste to produce building lime: Calcium oxide reactivity, industrial, environmental and economic implications. Mater. Struct. 2018, 51, 1-14. [CrossRef]

30. Ferraz, E.; Gamelas, J.A.F.; Coroado, J.; Monteiro, C.; Rocha, F. Recycling waste seashells to produce calcitic lime: Characterization and wet slaking reactivity. Waste Biomass Valoriz. 2018, 1-18. [CrossRef]

31. Tizo, M.S.; Blanco, L.A.V.; Cagas AC, Q.; Dela Cruz BR, B.; Encoy, J.C.; Gunting, J.V.; Arazo, R.O.; Mabayo, V.I.F. Efficiency of calcium carbonate from eggshells as an adsorbent for cadmium removal in aqueous solution. Sustain. Environ. Res. 2018, 28, 326-332. [CrossRef]

32. Darezereshki, E. Synthesis of maghemetute nanoparticles by wet chemical method at room temperature. Mater. Lett. 2010, 64, 1471-1472. [CrossRef] 
33. Aramend'1a, M.; Borau, V.; Jiménez, C.; Marinas, J.M.; Ruiz, J.R.; Urbano, F.J. Influence of the preparation method on the structural and surface properties of various magnesium oxides and their catalytic activity in the Meerwein-Ponndorf-Verley reaction. Appl. Catal. A Gen. 2003, 244, 207-215. [CrossRef]

34. Khan, M.D.; Ahn, J.W.; Nam, G. Environmental benign synthesis, characterization and mechanism studies of green calcium hydroxide nano-plates derived from waste oyster shells. J. Environ. Manag. 2018, 223, 947-951. [CrossRef] [PubMed]

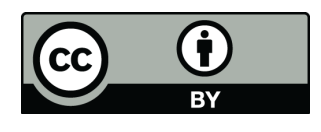

(C) 2019 by the authors. Licensee MDPI, Basel, Switzerland. This article is an open access article distributed under the terms and conditions of the Creative Commons Attribution (CC BY) license (http://creativecommons.org/licenses/by/4.0/). 